\title{
The Impact of Financial Crisis on Small and Medium Scale Enterprises Access to Credit in Nigeria
}

\author{
OWUALAH, Sunday I. (PhD) \\ Department of Finance, University of Lagos \\ OHAZEBERE Emmanuel \\ Department of Finance, University of Lagos
}

\begin{abstract}
In every economy of the world, the impact of the SME is not taken for granted as for all healthy economy, there must be a healthy SME due to the fact that, their contribution to the production volumes in terms of exports, innovations and the entrepreneur skills is vital for every economy to grow. There is a reasonable level of agreement among policy makers, theorists, economists, and business experts that small and medium enterprises (SMEs) are drivers of economic growth. SMEs' access to credit has been a serious subject of debates to policy makers and researchers of both developed and developing economies based on the pivotal and significant role of SMEs' in growing the private sector as well as the global economies as an extension to the nations. Hence, there is a need to examine the bank lending capacities to the SMEs' in Nigeria and its effects on the Nigerian business environment, the impact of financial crisis in Nigeria on SMEs' access to bank credit, in addition, to determine the impact of SMEs' on the Nigerian economy. The study employed the use of secondary source of data in the relevant literatures and data generated from the Central Bank of Nigeria Bulletin, 2016_on Credit Accessibility to the SME sector in Nigeria from the year 1992-2015. An econometric analysis was used specifically regression analysis. The result confirmed that Bank lending capacity as one of the factors of financial crisis does affect the SMEs access to credit, and there is a strong and positive relationship between the SMEAC, Foreign Direct Investment, Interest Rate and Inflation while there is a strong and negative relationship between the SMEAC, GDP Total, CBTC and the Money Supplied. However, there is a weak relationship between the SMEAC and the SMEGDP and CBLSME. The result indicates that, as the Interest Rate and Inflation continue to increase it has a negative influence on the SMEs access to credit through the commercial banks. It is recommended to the Nigerian government that, economic policies that would favour the establishment of more SMEs with access to flexible credit facilities be made. In addition, the government needs to improve on the commercial bank lending capacities to the SMEs as this when positively managed will positively influence the contribution of the SMEs GDP
\end{abstract}

Keywords: Financial Crisis, credit Accessibility, small and medium enterprises DOI: $10.7176 /$ RJFA/10-1-05

\section{Section I: $\quad$ Introduction}

In the world today, as established by the World Bank (2018) Small and medium enterprises contribution is put at about 90 percent of the available firms across the globe. Out of the total estimated 420-510 million of the formal and informal including the micro, small and medium enterprises present in the world, the larger percentage which amount to an estimate of about 365-445 million of the formal and informal micro, small and medium enterprise are situated in developing countries where Nigeria is a part (IFC 2010, 2011a,b,c). According to the Central Bank of Nigeria in the study of the informal sector in Nigeria, the number of MSMEs was estimated to be about 7 million with which an average of N50,000 funding is required yearly as a guesstimate of which the estimated total required finance is put at N350bn that is equivalent to about (US\$3bn) annually. It is established by some quarters that the type of finance to the SMEs in Nigeria is not limited to the promoters friends, including the family, the business angels, the venture capital funds, the capital markets, the debt-universal banks, the debt-microfinance banks, the quasi funds and the non-bank intermediaries; therefore, there is a probability of the SMEs of being credit constrained as the number of the SMEs increases on a daily basis.

SMEs' access to credit has been a serious subject of debate to policy makers and researchers of both developed and developing economies based on the pivotal and significant role of SMEs' in growing the private sector and by extension the economies of nations around the world. There exists diverse definition of the concept "access to finance". World Bank (2007) gave the definition of access to credit or finance as the "absence of price and non-price barriers in the use of financial services determined by the forces of demand and supply in the financial market". There is a reasonable level of agreement among policy makers, theorists, economists, and business experts that small and medium enterprises (SMEs) are drivers of economic growth. In every economy of the world, the impact of the SME is not taken for granted as for all healthy economy, there must be a healthy SME due to the fact that, their contribution to the production volumes in terms of exports, innovations and the entrepreneur skills is vital for every economy to grow. 
The strategic importance of SMEs' in propelling economic growth and development has been hampered by non-availability and non-access to finance to fund their activities. In Nigeria, despite the government efforts to intervene in SMEs' access to credit and finance, the SMEs still find it very difficult due to some constraints. It is established by Etuk, et al. (2014) that, the challenges which constitutes the problems faced by the SMEs are directly linked to the nation's economic variables as well as the difficulties that could be characterized collectively with the national economy. However, Ogujuiba, Ohuche, and Adenuga (2004) identified some reasons why the SMEs are still not performing as expected as recorded and listed by the Association of Nigerian Development Institutions in the year, 2004; which is due to lack of access to credit financing with the source of credit remaining the major factors hindering their contribution to the economic growth in Nigeria..

Making credit available to small scale business has been recognized as the major obstacles facing the majority of the SME business owners in Nigeria. However, the challenges which constitutes the problems faced by the SMEs' access to credit facilities are directly linked to the nation's economic variables as well as the difficulties that could be characterized collectively with the national economy (Etuk, et al., 2014). In the light of the aforementioned gaps with a scanty proper attention from the corporate finance and entrepreneurship literature, it becomes imperative, therefore, that more research be conducted to identify and suggest possible and/or workable solutions to the problems of SMEs' access to credit facilities/finance especially during a typical economic crisis which the country is currently undergoing.

Therefore the objective of the paper is to examine the bank lending capacities to the SMEs' in Nigeria and its effects on the Nigerian business environment, determine the impact of financial crisis on banks' lending capacity in Nigeria, determine the impact of financial crisis in Nigeria on SMEs' access to bank credit facilities in Nigeria and to determine the impact of SMEs' on the Nigerian economy. The working hypotheses are:

- Banks' lending capacity to SME's does not significantly influence SME's access to credit in Nigeria

- There is no significant impact of the lending capacity in the Nigerian economy on the financial crisis.

- $\quad$ Financial crisis does not significantly influence SME's access to credit in Nigeria

- There is no significant impact of the SME's on the Nigerian economy.

The result obtained will be very beneficial to entrepreneurship development as it will throw more sight to factors affecting the growth of Nigerian SME's bothering on financial credit availability to them bearing in mind their respective roles and importance to the Nigerian economy. The scope of this investigation is confined to the financial crisis and the economic situation of the Nigerian economy and its attendant effects on SMEs' access to bank credit. The paper is arranged in four sections; with section I, is the background of the study which comprises of objectives of the study, significance, scope and research hypotheses. Section II is the review of related literature, conceptual and theoretical frame work, while section III is methodology and analyses of data and section IV is the conclusion and recommendations.

\section{Section II: Literature Review}

Researchers on developmental economics have agreed that Small and Medium Scale Enterprises (SMEs) constitute the driving force of industrial growth and development and widely acknowledged as the springboard for sustainable economic development (Krugman 1993; Utomi, 2006). According to the United Nation Development Programme, 2014; developing countries including Nigeria, have since the 1970s shown increased interest in the promotion of small and medium scale enterprises for three main reasons: the failure of past industrial policies to generate efficient, self-sustaining growth; increased emphasis on self-reliant approach to development and the recognition that dynamic and growing SMEs' can significantly add to the nation's developmental plan and objectives. Hence, the development of SMEs' via effective financing options have generated academic debate and growing interest among researchers, policy makers and entrepreneurs, recognizing the immense contribution of the sub-sector to economic growth and development. Governments at various levels (local, state and federal levels) have in one way or the other focused on the support development entrepreneur spirit among her citizen in order to grow small and medium scale enterprises (SMEs') in the country for economic gains.

However, it seems that considering the significant potentials of the SMEs sector, and despite the acknowledgement of its huge contribution to sustainable economic development, its performance still falls below expectation in several developing countries.

\subsection{Conceptual Framework}

In the concept of the Small and Medium Scale Enterprises, there have been no accepted definitions as its classification is in three categories, namely: large, medium and small scales, which is a subjective and qualitative judgment (Ekpenyong, 2002) Secondly, small businesses are generally quite responsive to their environment and environment changes fast. The European Union (EU) Commission and the European Investment Bank generally define an SME as any firm with a workforce not exceeding 500, with net fixed assets of less than Euro 5 million, and with more than one third of its capital held by a larger company - these three conditions being cumulative. 
According to the house of the Lord's (2000) in Britain, small business is defined as that industry with an annual turnover of two (2) million pounds or less with fewer than 200 paid employees. Whereas in Japan (World Trade Organisation; 2001), it is defined according to the type of industry, paid up capital, and the number of paid employees. Although, the case is different in Japan where companies with 100 million Yen as well as having not less than 300 employees are classified to be a small and medium enterprise while the wholesale are those with not less than 30 million Yen with the number of employees not less than 100. In addition, the retail and services are those classified to have not less than 10 million Yen with the number of employees not less than 50.

But in Nigeria, the emphasis is on turnover and cost. The monetary policy of the Central Bank of Nigeria as determined in its circular No. 22 of 1988defined small scale enterprises as having an annual turnover not exceeding $¥ 500,000$.and for merchant banks loans those enterprises with capital investments not exceeding $\$ 2$ million (excluding the land cost) or which in total must not exceed $\$ 5$ million. The National Council on Industries (NCI) at its $13^{\text {th }}$ meeting in Makurdi in 2001 defined it in this category as:

Table 1.1. Enterprise Category

\begin{tabular}{|l|l|c|c|}
\hline s/n & Enterprise Category & Asset Worth $\left(N^{\prime} \mathrm{m}\right)$ & No. of Employee \\
\hline 1. & Micro & 1.5 & 10 \\
\hline 2. & Small & 50 & 100 \\
\hline 3. & Medium & 200 & 300 \\
\hline
\end{tabular}

\subsection{Model Analysis}

In management, the word "Environment" does not necessarily mean physical surroundings, but is used to describe all those influences that bear upon corporate organisations as it affect decision making in totality. This environment is a complex, multi-focus dynamic and has a far reaching effect on such organisation. In banking business, the environment constraint the lending policy and how much loan facility is made available to the lender. In the case of banks in Nigeria, the lending ability of the banks is constrained by a decline in foreign reserves, which lead to the financial crisis in the country. In order to liberalise the system, the government made policies that ease funds for certain sectors of the economy. On some occasion government give support to SMEs by directing the banks to direct a certain percentage of their loanable fund to SMEs. In summary, the quantity and amount of loanable funds available to SMEs' are directly dictated by the business environment.

Government support may be directed to SMEs through Small and Medium Enterprises Development Agency (SMEDAN) by giving technical advices and training to SMEs. Access to the fund will enable the SMEs to perform their role of generating employment, production of goods and services, generating needed foreign exchange for the country and the same time pay tax and excise duties on export goods. All these will lead to economic growth and development for the country.

Conceptual Model

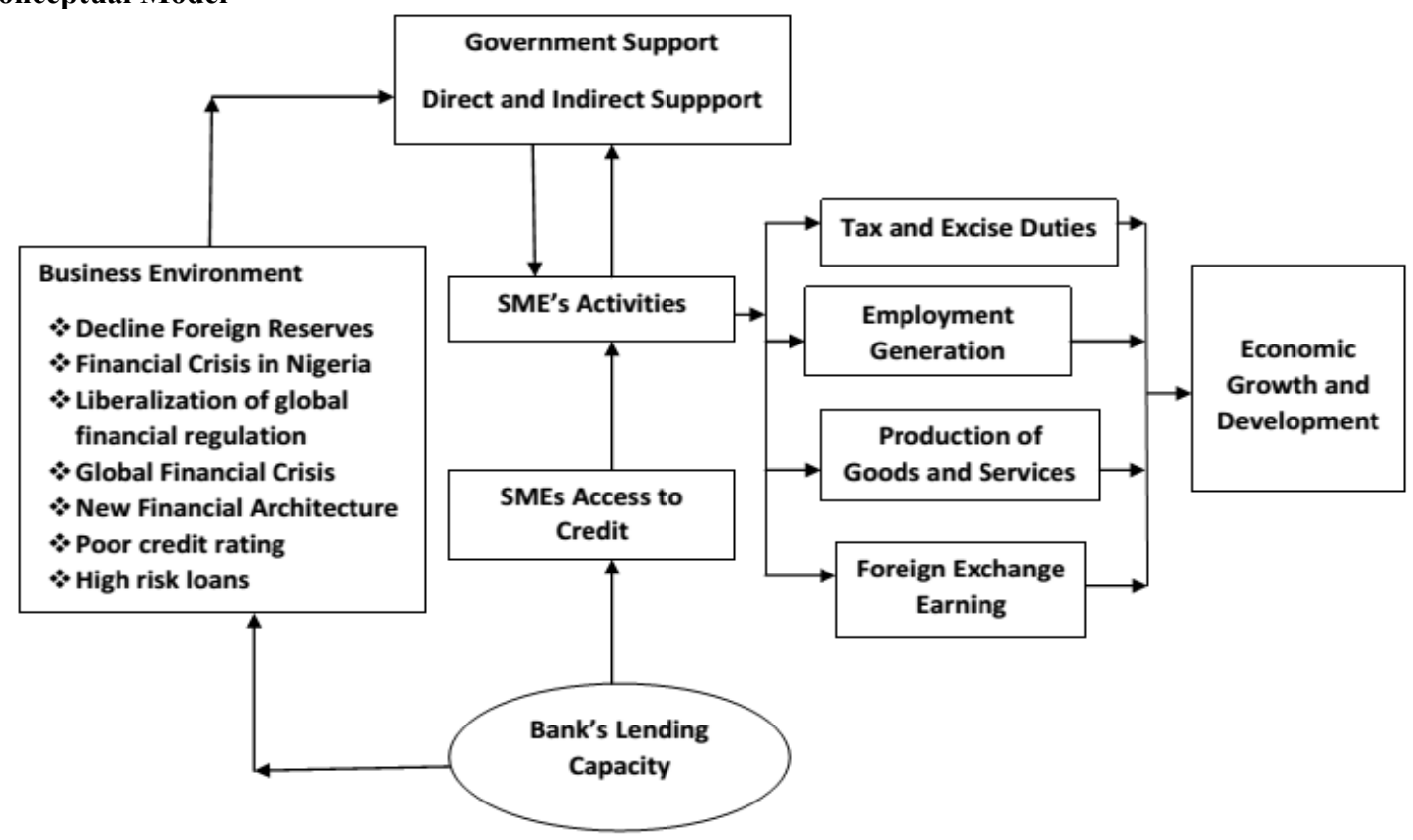

Figure 1.1: Conceptual Model

Source: Researcher's Model (2018) 


\subsection{Financial Crisis}

International Monetary Fund,2013; observed that financial crises have common elements, that comes in many forms. IMF however identified the following phenomena as common elements;

* substantial changes in credit volume and asset prices;

* severe disruptions in financial intermediation and the supply of external financing to various actors in the economy; large scale balance sheet problems (of firms, households, financial intermediaries and sovereigns); and

* large scale government support (in the form of liquidity support and recapitalization).

It is very difficult to characterize the financial crisis with a single indicator or variables as the event is multidimensional in nature. Utomi (2016), observed that though literature has clarified some of the factors driving crises, but it remains a challenge to definitively identify their deeper causes. Over the years, several theories were developed with respect to the causes of the financial crisis across the globe by scholars. Yet, by not achieving the exact causes of the financial crisis, the fundamental factors such as macro-economic imbalance, internal shocks and external shocks were observed as part of the cause. Sometimes, it could be caused by irrational factors such as sudden runs on banks, contagion and spill-over among monetary markets, limits to arbitrage throughout times of stress, emergence of asset busts, credit crunches, and fire-sales, and different aspects associated with monetary turmoil.

Today, according to research, a variety of situations which involves financial institutions' assets losing a substantial part of their value is called a financial crisis. Financial crises directly result in a loss of paper wealth; they do not directly result in changes in the real economy, it may indirectly do so if a recession or depression follows.

\subsection{Financial Crisis in Nigeria}

Banks and other financial institutions are the established institutions where credit facilities are to be sought by SMEs in financing their businesses across the world. Failure in their responsibilities due to some constraints such as government policies and market crashing as a result of the financial crisis has caused them not to be stable in their responsibilities. Today, according to research, a variety of situations which involves financial institutions' assets losing a substantial part of their value is associated with the financial crisis which could be national, continental and/or global which as a result have a direct and a significant effect on the SMEs access to funds (Alexander,2017). The crunch in the US sub-prime mortgage market in 2008 was the major factor that triggered the credit crunch which let to the global financial crisis that spreads over many countries in the world which was deepened in some countries. The effects of the financial crisis with respect to the Nigeria economy is packed with dissimilar consequences on the Nigerian capital market, the banking segment, the foreign exchange section, the balance of payment and the real sector.

The result of the monetary crisis that began within the United States of America (USA) on the rising markets was wide-ranging and were internally and outwardly induced (Nijathaworn, 2010). The initial monetary crisis had affected mostly America and Europe. However, because of the connectivity of the national economy conjointly called the "contagion effect"e most economies were affected. In the mid 2007 was when Nigeria began to experience the implication of the financial crisis with the major effects on the stock market prices. In 2009, the new phase began as a result of the collapse of the Lehman Brothers which later spread over the economic segments of the advanced, emerging as well as the developing economies in the world where Nigeria fall a victim.

Considering the behavior of the Nigerian economy, the foreign exchange market was affected by the financial crisis which later resulted to the foreign investors repartriating their capital and dividends by disinvesting it which later created pressure on the foreign currencies. The consequence of this affected the Nigerian foreign reserves as it was depleting. Various segement of the Nigerian economy suffered this. Firstly, there was a steady fall in the share index and the volume of the securities traded in the Nigerian stock market.

Secondly, the banking sub-sector was affected by a credit contraction as most foreign banks reduced their credit lines, exchange rate exposure, and the continuous decline in the NSE eroded their profitability. Thirdly, the fall within the revenue recipts by the 3 tiers of government resulting in a contraction within the financial sector. In the course of the tightening in the fiscal sector of the economy resulted into the crowding-out of the entire private sector credit that later affects the real sector.

\subsection{Financial System and SMEs in Nigeria}

Finance is the lifeline and an important resource needed for the day to day operation of any business activities of any organisation either small or large conglomerate, basically no business organisation can survive without finance. The need for finance varies from time to time and from one form to another, either at the start up stage, growth or expansion stage, or beyond, irrespective to the size of a business (that is whether micro, small, medium or large). Easy access to credit has been identified as one of the most factors for the creation, survival 
and growth of Small and Medium Scale Enterprises (SMEs) globally. International Finance Corporation (IFC 2010) observed from Enterprise surveys conducted by the World Bank that SMEs face more severe financing constraints than large firms. Access to fund by SMEs are limited and usually not attractive to large investors, except for the new trend of some commercial banks establishing which established SMEs units, usually SMEs do not have specialized institutions focused on their peculiar finance needs. Commercial banks lend to SMEs at similar rates that do give to large corporations, and sometimes even at higher rates due to issues of risk (Oloye; Obadiaru, and Bamigbola; 2015).

Several studies have concluded that global crises have direct impact on banks, which has further constraints the availability of credit to SME, as banks prefer to lend to large enterprises than small and medium (Adamu, 2009; Ayadi, 2008). An assessment of the relationship that exists between the SMEs and Nigerian financial system shows clearly the existence of an apathy that is directed towards small businesses by the financial system and resentment on the part of the SMEs towards the financial system (FS). Despite the numerous moves by the government to pursue developmental programs before the financial crisis, there exists the 1970 Mandatory Credit Guideline, the 1971 Small Scale Industries Credit Guarantee Scheme; the 1973 Agricultural Credit Guarantee Scheme, Nigeria Agriculture and Co-operative Bank,the Nigerian Bank for Commerce and Industry; the 1977 Rural Banking Scheme, the 1988 African Development Bank - Export Stimulation Loan Scheme (ADB-ESL), the 1989 Peoples Bank, the 1992 National Economic Reconstruction Fund,the 1992 Small and Medium Scale Enterprises Loan Scheme, the 1997 Family Economic Advancement Program; the 2001 duo of the Bank of Industry (BOI)and; Small and Medium Enterprises Equity Investment Scheme (SMEEIS') in 2001 which is aimed at solving the SME finance gap problem, under which $10 \%$ of the profit after tax of Banks is reserved for SME financing. These have not had any observable effect on SME financing. This may be due to the poor managerial ability or as results of low entrepreneurial skills; SMEs in Nigeria were not being able to maximally benefit from the equity.

According to Ogujiuba, Ohuche and Adenuga (2004) creating an entrepreneurial initiative is one thing, but accessing the necessary finance to translate such ideas into reality is another. Many novel entrepreneurial ideas have been known to die simply because the conceivers or originators could not fund them, and the banks, which could have been their last resort as there is no guarantee worth investing in Finance.

\subsection{Theoretical Framework}

The theoretical framework adopted in the paper involved the bank capital channel model, the Lifecycle approach and the Pecking-order theory that attempts to explain small-firm financial structuring.

\section{Bank Capital Channel Model}

The "bank capital channel" relies on 3 hypotheses; firstly, there needs a good look at an imperfect marketplace for bank equity; where banks cannot easily issue new equity for the existence of bureau costs and tax disadvantages (Myers and Majluf, 1984; Calomiris and Hubbard, 1995). Secondly, the interest rate risk is one of the banks associated problems attached to a higher maturity with respect to liabilities known as maturity transformation. Third, regulatory capital requirements limit the supply of credit (Bolton and Freixas, 2001; Van den Heuvel, 2001).

The model of credit facilities disbursal behaviors of bankers to entrepreneurs are highlighted as it greatly concerns the capital adequacy prerequisite. The model looks at interest rate volatility as a determining factor to their financial treatment, particularly when their credit offer is tense down by the strength of their capital-base. The implication is that, often, as interest rates increase, the funding cost of banks' external funding also increases, thereby reducing profit tendencies. It is therefore a necessary tool to the bankers as it gives a guide on when the bankers need to adjust downward the credit related issues most especially when there is a constraint on the capital-base.

The mechanism is that following an increase in the market interest rates, a lower fraction of loans can be renegotiated with respect to deposits (loans are mainly long term, deposits are of a short-term): where the negative effects bounce on the banks while the maturity mismatching that steadily diminish the profit as well as the capital. The bank capital channel theory also applies to capital requirement which is not currently binding. In order to lower the future risks of the capital inadequacy, the low-capitalised financial institutions needs to optimally forgo the crdit disbursal opportunities at earlier time (Van den Heuvel, (2001).

This is interesting because in reality, when the interest rate is high, it directly increases the external funding with loans in a long-term and deposit a short-term while financial institutions are guided by their policies on SMEs funding and take appropriate decisions on small and medium enterprise funding as most banks are not constrained at any given time. There is a need to note the negative impact of the financial tightening on the credit facilities disbursal could be generated by the banks in a perfect marketplace that might result into a nonreservable liabilities according to the bank capital channel is also worth noting that, according to the "bank capital channel", a negative effect of a monetary tightening where loaning may well be sourced additionally if the banks face an ideal market for non-reservable liabilities.. 


\section{The Lifecycle Theory}

The life-cycle hypothesis suggests that people set up their consumption and savings behaviour over their lifecycle. Most times, their intention is to even out consumption within the very best manner over their entire lifetimes, which therefore results in accumulation when they earn and dis-saving when they are retired. The key assumption is that every person decides on what stable lifestyles they wish to live. The indication of this is that, failure to save enough in one period prevents furious spending in the next period which leads to maintaining a constant level of consumption at every period.

This theory was developed by an Economists Modigliani and Brumberg, (1954) and later modified by other Scholars (Modigliani and Ando, 1957; Ando and Modigliani, 1963). The Life-cycle hypothesis has been severally employed in the various financial areas to examine the behaviour of savings and the retirement plan for older persons. However, it works by observing the variation in the consumption needs as well as the income by examining numerous points on the life-cycle.It is of note that document evolution in every financing business environment happens at different stages, but it was established that unclear information might be one of the factors to generate the pattern (Berger and Udell, 1998). Robb and Robinson (2012) confirm this pattern with a new and more detailed dataset. A large body of literature tries to explain the entrepreneur's choice of financing method at certain stages (Rajan, 1992; Boot and Thakor,1994; Peterson and Rajan, 1994). A notable exception which focuses on the life cycle of firm financing is Rajan (2012). The author argues that the entrepreneur's choice between internal and external funding sources is determined by the tradeoff between differentiating her enterprise to generate higher net present value and standardizing her enterprise to lower external funding cost, the relationship between SMEs' in pursuit of speedy growth and the challenge of poor access to capital market. The theory stated that SMEs are perceived to be starting out by exploring only the owners' resources. The dynamic small firm prefers to choose between curtailing its growth to keep in line with its minimally generated funds, get an expensive stock market quotation, or desires an almost impossible volume venture capital according to Weston \& Brigham(1981).

\section{The Pecking Order Theory}

In 1984, Myers and Majiluf popularized the pecking order theory with the argument between the equity and the means to raise capital where it was claimed that, equity is less preffered means because when managers (who assumed to know better about the true condition of the firms than investors) issue new equity, where the investors practically thinks that the managers take the advantage of the firm overvaluation as assumed when it is not being overvalued by the investors. . As a result of this, investors see no reason of placing high values on the new equity issuance.

Myer (1984), posited that most firms will resort to meeting their financial needs in an order of hierarchy; firstly by the use of internally generated funds, secondly borrowing resulting into debt, and thirdly where equity is used to generate funds. Commonly, this practice is predominantly in small firms and implies the inverse link between profitability and borrowings.

\section{Section III: Research Methodology}

In achieving the goals of the study, the data for the study was collected through secondary sources from the Central Bank of Nigeria Bulletin, 2016 on Credit Accessibility to the SME sector in Nigeria from the year 19922015.

The model specification for the regression analysis test of hypotheses is given as;

$$
\text { SMEAC }=\mathrm{f}(\text { GDPTotal, SMEGDP, FDI, CBLSME, CBTC, IR, MS, INF) }
$$

$$
\text { SMEAC }=\beta_{0}+\beta_{1} \text { GDPTotal }+\beta_{2} \text { SMEGDP }+\beta_{3} \text { FDI }+\beta_{4} \text { CBLSME }+\beta_{5} \text { CBTC }+\beta_{6} \mathrm{IR}+\beta_{7} \mathrm{MS}+\beta_{8} \mathrm{INF}
$$

$$
+\mathrm{e}
$$

Where;

SMEAC $=$ SME's Access to Credit

GDPTotal $=$ Total Gross Domestic Product

SMEGDP $=$ SMEs' Contribution to GDP

FDI= Foreign Direct Investment

$\mathrm{CBLSME}=$ Commercial Bank Lending to SMEs (Billion Naira)

$\mathrm{CBTC}=$ Commercial Banks Total Credit (N'm)

$\mathrm{IR}=$ Interest Rate

MS $=$ Money Supplied (N'B)INF $=$ Inflation Rate $\beta_{0}=$ Intercept

$\beta_{1}$ to $\beta_{8}$, = Slope of the linear equation

$\mathrm{e}=$ Error term

The econometric model is to capture the structural changes that exist in the relationship between macroeconomic indicators and national industrial output before and during the global economic crisis. However, for the essence of examining the effect of financial crisis on SME's access to credit in Nigeria, this study employed structural stability regression model indicators and national industrial output before and during the global economic crisis. The major macroeconomic indicators expected to be shockingly responsive between the 
Pre-crisis and crisis periods are Foreign Direct Investment in manufacturing and processing sector (FDIM), Bank Leading Rate (LEN), Trade Balance (TRB), Inflation Rate (INF), Exchange Rate (EXC) and World Oil Price (WOP). While, National Industrial Output (IGDP) is used to proxy the contribution of manufacturing industry to total Gross Domestic Product (GDP) in Nigeria. Therefore, the econometric models are specified as:

\section{Pooled periods:}

$\mathrm{IGDP}=\mathrm{FDIM}+\mathrm{LEN}+\mathrm{TRB}+\mathrm{INF}+\mathrm{EXC}+\mathrm{WOP}+\mathrm{u}$

Pre-Crisis period:

$\mathrm{IGDP}=\mathrm{FDIM}+\mathrm{LEN}+\mathrm{TRB}+\mathrm{INF}+\mathrm{EXC}+\mathrm{WOP}+\mathrm{u}$

The variables considered for analysis include Gross Domestic Products, Foreign Direct Investment, the SME Gross Domestic Products in the Nigerian economy, CBLSME, CBTS, SMEAC, Interest Rate and the Money Supplied.

Empirical Analysis

Table 3.1. Descriptive Properties

$\begin{array}{lccccccccc} & \text { SMEAC } & \text { GDPTOTAL } & \text { SMEGDP } & \text { FDI } & \text { CBLSME } & \text { CBTC } & \text { IR } & \text { MS } & \text { INF } \\ \text { Mean } & 9.742500 & 25966.77 & 1.063333 & 3.445833 & 167.6752 & 3943.921 & 13.52083 & 5343.042 & 19.66667 \\ \text { Median } & 5.100000 & 10662.30 & 1.030000 & 3.150000 & 33.27875 & 1364.638 & 13.50000 & 2042.500 & 12.00000 \\ \text { Maximum } & 48.80000 & 94144.96 & 2.470000 & 10.80000 & 3237.405 & 12445.71 & 26.00000 & 18901.00 & 73.00000 \\ \text { Minimum } & 0.120000 & 875.3400 & 0.010000 & 0.700000 & 11.30800 & 41.81000 & 6.000000 & 111.0000 & 5.000000 \\ \text { Std. Dev. } & 12.58489 & 30907.89 & 0.744538 & 2.270028 & 654.2122 & 4459.856 & 4.272585 & 6227.359 & 18.66330 \\ \text { Skewness } & 1.556491 & 1.161792 & 0.221912 & 1.751954 & 4.579041 & 0.654383 & 0.837247 & 0.958676 & 1.740524 \\ \text { Kurtosis } & 5.018684 & 2.782327 & 1.763523 & 6.418372 & 21.99493 & 1.681210 & 4.633431 & 2.455251 & 4.713155 \\ & & & & & & & & & \\ \text { Jarque-Bera } & 13.76574 & 5.446427 & 1.725856 & 23.96264 & 444.6777 & 3.452076 & 5.472031 & 3.972988 & 15.05260 \\ \text { Probability } & 0.001025 & 0.065663 & 0.421925 & 0.000006 & 0.000000 & 0.177988 & 0.064828 & 0.137176 & 0.000539 \\ & & & & & & & & & \\ \text { Sum } & 233.8200 & 623202.5 & 25.52000 & 82.70000 & 4024.206 & 94654.10 & 324.5000 & 128233.0 & 472.0000 \\ \text { Sum Sq. Dev. } & 3642.728 & 2.20 \mathrm{E}+10 & 12.74973 & 118.5196 & 9843852 . & 4.57 \mathrm{E}+08 & 419.8646 & 8.92 \mathrm{E}+08 & 8011.333\end{array}$

$\begin{array}{llllllllll}\text { Observations } & 24 & 24 & 24 & 24 & 24 & 24 & 24 & 24 & 24\end{array}$

Source: Author's findings, 2018

The descriptive summary of the variables over a period of 24years is presented in Table 3.1 above which covers the small and medium enterprise access to credit, the gross domestic product total, the small and medium enterprise gross domestic product, the foreign direct investment, commercial bank loans to small and medium scale enterprise, the commercial bank total credit, the interest rate on loans, the money supplied and the Nigeria inflation figures from 1992 to 2015. However, there has been a crude improvement on the SMEs access to credit with a percentage increase of 40,567 percent and a mean of 9.7; the gross domestic products improve with a percentage increase of 10,655 percent and a mean of 25,967; the SME contribution to the gross domestic product is with a percentage increase of 24,600 percent and a mean of 1.1 ; the foreign direct investment is with a percentage increase of 1443 percent and a mean of 3.4; the commercial bank loan to the SMEs is with a percentage increase of 28,529 and a mean of 168; the commercital bank total credit is with a percentage increase of 29,667 pecent and a mean of 3,944; the interest rate is with a percentage increase of 333 percent and a mean of 14 , the money supplied is with a percentage increase of 16,928 percent with a mean of 5343 and the percentage increase of inflation is 1360 percent and a mean of about 20 percent from 1992 to 2015 .

\begin{tabular}{|c|c|c|c|c|c|c|c|c|c|}
\hline \multirow[t]{2}{*}{ Table 3.2} & \multicolumn{3}{|c|}{ Correlation Coefficients } & \multirow[b]{2}{*}{ FDI } & \multirow[b]{2}{*}{ CBLSME } & \multirow[b]{2}{*}{ CBTC } & \multirow[b]{2}{*}{$\mathbb{R}$} & \multirow[b]{2}{*}{ MS } & \multirow[b]{2}{*}{ INF } \\
\hline & SMEAC & SMEGDP & GDPTOTAL & & & & & & \\
\hline SMEAC & 1.000000 & 0.280316 & -0.579240 & 0.496011 & 0.223322 & -0.651601 & 0.593151 & -0.618641 & 0.738683 \\
\hline SMEGDP & 0.280316 & 1.000000 & -0.068219 & 0.366460 & -0.013914 & 0.043844 & -0.050081 & -0.049275 & 0.424837 \\
\hline GDPTOTAL & -0.579240 & -0.068219 & 1.000000 & -0.593944 & -0.176607 & 0.911507 & -0.431580 & 0.981724 & -0.406922 \\
\hline FDI & 0.496011 & 0.366460 & -0.593944 & 1.000000 & 0.032191 & -0.494026 & 0.295202 & -0.553714 & 0.630698 \\
\hline CBLSME & 0.223322 & -0.013914 & -0.176607 & 0.032191 & 1.000000 & -0.201346 & 0.009484 & -0.191796 & 0.603720 \\
\hline CBTC & -0.651601 & 0.043844 & 0.911507 & -0.494026 & -0.201346 & 1.000000 & -0.594228 & 0.962074 & -0.439615 \\
\hline $\mathbb{R}$ & 0.593151 & -0.050081 & -0.431580 & 0.295202 & 0.009484 & -0.594228 & 1.000000 & -0.508262 & 0.418022 \\
\hline MS & -0.618641 & -0.049275 & 0.981724 & -0.553714 & -0.191796 & 0.962074 & -0.508262 & 1.000000 & -0.426707 \\
\hline INF & 0.738683 & 0.424837 & -0.406922 & 0.630698 & 0.603720 & -0.439615 & 0.418022 & -0.426707 & 1.000000 \\
\hline
\end{tabular}

Source: Author's findings, 2018

Table 3.2 presents the correlation coefficients between the economic variables under investigation. The correlation of all the independent variables is compared with the dependent variable (SMEAC) and the results revealed that there is a strong and positive relationship between the SMEAC, Foreign Direct Investment, Interest Rate and Inflation while there is a strong and negative relationship between the SMEAC, GDPTotal, CBTC and the Money Supplied. However, there is a weak relationship between the SMEAC and the SMEGDP and CBLSME. This indicates that, as the Interest Rate and Inflation continue to increase it has effects on the SMEs 
access to credit through the commercial banks.

The Granger Causality Tests were carried out to examine the causality of the pairwise variables under investigation, and the result shows the F-Statistic and the probability value at lag one. It is observed from the result that, the SME contribution to the gross domestic product, total gross domestic products, foreign direct investment, commercial bank total credit and money supplied do not Granger Cause the SMEs access to credit as the p-values are greater than the 5percent threshold while CBLSME and Inflation Granger Cause the SMEs access to credit. (see Table 3.3) This shows that, the commercial bank loan to the small and medium enterprises as well as the inflation have visible effects on the SMEs access to credit which worth to be noted by the policy makers. This is an indication that, rise in price of commodities would have effect on the access to credit by the SMEs in Nigeria.

Table 3.3: Granger Causality Test of the independent variables with the SMEs access to credit.

Pairwise Granger Causality Tests

Date: 07/16/18 Time: 08:53

Sample: 19922015

Lags: 1

\begin{tabular}{|c|c|c|c|}
\hline Null Hypothesis: & Obs & F-Statistic & Prob. \\
\hline SMEGDP does not Granger Cause SMEAC & 23 & 0.28495 & 0.5994 \\
\hline SMEAC does not Granger Cause SMEGDP & & 1.20698 & 0.2850 \\
\hline GDPTOTAL does not Granger Cause SMEAC & 23 & 0.91740 & 0.3496 \\
\hline SMEAC does not Granger Cause GDPTOTAL & & 1.20352 & 0.2857 \\
\hline FDI does not Granger Cause SMEAC & 23 & 2.52509 & 0.1277 \\
\hline SMEAC does not Granger Cause FDI & & 17.1020 & 0.0005 \\
\hline CBLSME does not Granger Cause SMEAC & 23 & 12.4386 & 0.0021 \\
\hline SMEAC does not Granger Cause CBLSME & & 1.06412 & 0.3146 \\
\hline CBTC does not Granger Cause SMEAC & 23 & 1.33820 & 0.2610 \\
\hline SMEAC does not Granger Cause CBTC & & 2.50028 & 0.1295 \\
\hline IR does not Granger Cause SMEAC & 23 & 0.01874 & 0.8925 \\
\hline SMEAC does not Granger Cause IR & & 7.45345 & 0.0129 \\
\hline MS does not Granger Cause SMEAC & 23 & 1.19139 & 0.2880 \\
\hline SMEAC does not Granger Cause MS & & 3.97022 & 0.0601 \\
\hline INF does not Granger Cause SMEAC & 23 & 11.8574 & 0.0026 \\
\hline SMEAC does not Granger Cause INF & & 2.82055 & 0.1086 \\
\hline
\end{tabular}

Source: Author's findings, 2018 
Table 3.4: Model Summary

\begin{tabular}{|c|c|c|c|c|c|c|c|c|c|c|}
\hline \multicolumn{11}{|c|}{ Model Summary $^{\mathbf{b}}$} \\
\hline \multirow[b]{2}{*}{ Model } & \multirow[b]{2}{*}{$\mathrm{R}$} & \multirow[b]{2}{*}{ R Square } & \multirow[b]{2}{*}{$\begin{array}{l}\text { Adjusted R } \\
\text { Square }\end{array}$} & \multirow{2}{*}{$\begin{array}{l}\text { Std. Error } \\
\text { of the } \\
\text { Estimate }\end{array}$} & \multicolumn{5}{|c|}{ Change Statistics } & \multirow[b]{2}{*}{$\begin{array}{l}\text { Durbin- } \\
\text { Watson }\end{array}$} \\
\hline & & & & & $\begin{array}{c}\text { R Square } \\
\text { Change }\end{array}$ & F Change & df1 & $\mathrm{df} 2$ & $\begin{array}{c}\text { Sig. F } \\
\text { Change }\end{array}$ & \\
\hline 1 & $0.911^{\mathrm{a}}$ & 0.830 & 0.739 & 6.42987 & 0.830 & 9.139 & 8 & 15 & .000 & 0.963 \\
\hline
\end{tabular}

a. Predictors: (Constant), Inflation, Gross Domestic Product (Total), SME GDP Contribution, Interest Rate,

Foreign Direct Investment, Commercial Bank Lending to SME, Commercial Bank Total Credit, Money Supplied

b. Dependent Variable: SMEs' Access to Credit

$\mathrm{L}=0.666, \mathrm{U}=2.318$

Source: Author's findings, 2018

The model summary of the global test as presented in Table 3.4 above tells us that, about 91percent of the proportion variation of the SMEs access to credit could be explained by all the factors causing financial crisis, the R--square is about 83percent proportion of variation of the SMEs access to credit could be explained by the factors causing financial crisis in Nigeria while the coefficient of determination is about 74percent of the SMEs access to credit that could be explained by the factors causing financial crisis. It is shown from the Durbin Watson statistic that, $(\mathrm{d}=0.963)$ shows that there is a positive autocorrelation as the value is getting near to zero. Table 3.5: Analysis of Variance

\begin{tabular}{|c|c|c|c|c|c|c|}
\hline \multicolumn{7}{|c|}{ ANOVA $^{a}$} \\
\hline \multicolumn{2}{|c|}{ Model } & Sum of Squares & df & Mean Square & $\mathrm{F}$ & Sig. \\
\hline \multirow[t]{3}{*}{1} & Regression & 3022.579 & 8 & 377.822 & 9.139 & $0.000^{\mathrm{b}}$ \\
\hline & Residual & 620.149 & 15 & 41.343 & & \\
\hline & Total & 3642.728 & 23 & & & \\
\hline \multicolumn{7}{|c|}{ Dependent Variable: SMEs' Access to Credit } \\
\hline \multicolumn{7}{|c|}{$\begin{array}{l}\text { b. Predictors: (Constant), Inflation, Gross Domestic Product (Total), SME GDP Contribution, Interest Rate, } \\
\text { Foreign Direct Investment, Commercial Bank Lending to SME, Commercial Bank Total Credit, Money } \\
\text { Supplied }\end{array}$} \\
\hline
\end{tabular}

Source: Author's findings, 2018

The ANOVA result as presented in Table 3.5 shows that the model is a good fit to determine the effect of the SMEs access to credit from the commercial banks with the p-value $(0.000)$ less than the 5 percent threshold. It could be established that, financial crisis either at recession or at depression have greater effect on the SMEs access to credit in Nigeria. It is thus evident that the considered financial crisis factors, total gross domestic product, SME gross domestic product, interest rate, foreign direct investment, commercial bank lending to SMEs, commercial bank total credit and the money supplied into the Nigerian economy over a period of 24years, 1992 to 2015 have significant effects on the access to credit by the small and medium enterprises in Nigeria.

It was also discovered that Bank lending capacity as one of the factors of financial crisis does affect the SMEs access to credit. It is obvious that, evaluating the Nigerian business environment; the high interest rate discourages the SMEs start-up as well as the existing SMEs. The commercial bank total credit to the SMEs determines the number of SMEs that would have access to the credit for growth and business development, while the money supplied by the central bank of Nigeria to the banks also affects the access to credit of the SMEs in Nigeria.

it is revealed that, gross domestic product (total), foreign direct investment, commercial bank lending to the SME and inflation have significant effects in determining the SMEs access to credit in Nigeria.

\section{Section IV: $\quad$ Recommendations and Conclusion \\ 4,1 Recommendations}

As a result of the analysis of the findings above, it is necessary for the researcher to recommend to the government on the areas which needs some improvement in order to improve the Nigerian economy and as well to prepare for the future financial crisis. The recommendations are as follows:

- As the government is the controller of all institutions within its territory, there is a need for the government to make working policies through the Central Bank of Nigeria on the interest rate charged by the financial institutions across the country on the credit facilities to the SMEs' with adequate supervision to exempt saboteur off from the process while the financial institutions are checked on their attitudes and activities on the credit facilities to the SMEs in order to grow the economy.

- The Nigerian government, due to the contribution of the SMEs in the national GDP should make policies that would favour the establishment of more SMEs with access to flexible credit facilities. If this is fulfilled by the government, it would continuously improve the economy against the future 
financial crisis.

- The government needs to improve on the commercial bank lending capacities to the SMEs as this is positively managed will positively influence the contribution of the SMEs GDP as there would be an increase in banking deposit which then forms an unending process that will continuously improve the economy

\subsection{Conclusion}

In all countries of the world, SMEs gives a larger proportion input in the economy by helping the government to reduce the rate of unemployment in the country. It is deduced from the findings that, high interest rate on credit facilities to the SMEs in Nigeria has been a retarding force dragging the Nigerian economy backward such that the SMEs are reluctant to access credit facilities as they are not sure of how to manage the facilities to achieve the SMEs' objectives. Therefore, the value of the interest rate largely discourages SMEs' to obtain credit facilities from the financial institutions in Nigeria. Irrespective of the intervention by the government to improve upon the SMEs having access to credit through several financial policies, it shows that the policies are not contributing to the improvement of the SMEs access to credit in Nigeria.

However, it is established from the outcome of the findings that, SMEs' contribution to the economic growth in Nigeria in terms of the Gross Domestic Product of the SMEs, the majority of the SMEs derived their source from the personal savings, gifts or money borrowed from the members of the family. This has caused the country an irregular movement on the contribution of the SMEs' into the economy. It is established from the findings that bank lending capacity has been one of the major factors that resulted in the financial crisis, which had a significant impact on the performance of the SMEs access to credit in the Nigerian economy. Moreover, the findings revealed that, there is a significant impact of the lending capacities of the financial institutions as it causes the financial crisis. However, the Gross Domestic Product and the lending capacities have among other factors, have higher influence to cause a financial crisis in a country that its economy is largely relied on the SMEs contribution. It is thus very essential that the lending capacities of the Nigerian banks are being worked on by the government in terms of viable financial policy on credit facilities as it has a direct impact on the Gross Domestic Products that measures the overall performance of the Nigerian economy.

Furtherance to the findings, it is vivid that the majority of the SMEs in Nigeria suffers in accessing credit from the commercial banks or any other financial institution due to the financial crisis. This was majorly caused by the Gross Domestic Product of Nigeria, the commercial lending capacities, the Foreign Direct Investment and Inflation. All this as an attribute to the cause of financial crisis directly affects the SMEs access to credit facilities. Therefore, there is a need for the government to work on the economy by finding solutions on how to improve on the Gross Domestic Products, Foreign Direct Investment and the Commercial Bank Lending which in turn will reduce the inflation figure. As the government works on the commercial bank lending capacities, it will directly influence the access to credit by the SMEs which in turn reflect on the Gross Domestic Products.

The non-performance of the SMEs in the Nigerian economy could be attributed to the way the government sees the impact of the sector in the economy as well as policies that (1) do not favour the SMEs and (2) being sabotaged by the politicians for a political gain.

\section{REFERENCES}

Avery, R. B., Bostic, R. W. \&Samolyk, K.A (1998). The role of personal wealth insmall business finance. Journal of Banking and Finance 22, 1019-1061.

Ayyagari, M., Beck, T. \&Demirgüç-Kunt, A. (2003). Small and Medium Enterprises across the Globe: A New Database, World Bank Publications Vol. 3127.

Bannock, Graham, Matthew Gamser, MariellJuhlin and Andrew McCann (2002)."Indigenous Private Sector Development and Regulation in Africa and Central Europe: A 10 Country Study”, Bannock Consultants, London, August.

Berger, A. and Udell, G. (2005).A more complete conceptual framework for financing of small and medium enterprises. World Bank Policy Research Working Paper 3795(12), 2005.

Central Bank of Nigeria (2017). The Nigerian Financial System at a Glance. Monetary Policy Department.

Cowling, M., Liu, W. \& Ledger, A. (2012). Small business financing in the UK before and during the current financial crisis.International Small Business Journal 30(7):778-800.

Eric, E. A. (2016). Challenges Faced by SMEs when Accessing Fund from Financial Institutions in Ghana. Unpublished Thesis of the Business Economics and tourism, Vaasan Ammattikorkeakoulu University of Applied Sciences, International Business.

Etuk, R. U., Etuk, G. R., and Baghelo M. (2014). Small and Medium Scale Entwerpises (SMEs) and Nigeria's Economic Development. Mediterranean Journal of Social Sciences. Vol. 5 No. 7, pp. $656-662$

Filippetti, A. and Archibugi, D. (2011). Innovation in times of crisis: National systems of Innovation, structure and demand. Research Policy. 40: 179 - 192. 
Frimpong, C. Y. (2013). SMEs as an Engine of Social and Economic Development in Africa. Modern Ghana featured Article Retrieved from http://www.modernghana.com, july 2016.

Gbandi, E. C. \&Amissah, G.(2014). Financing options for small and medium enterprises in Nigeria.European Scientific Journal 10 (1), 1857 - 7881.

Gulani, M., G. \&Usman, A. (2013).Financing small and medium scale enterprises (smes): a challenge for entrepreneurial development in Gombe state.Asian Journal of Business and Management Sciences, 2 (9), 17-23.

Hasnah, H., Saniza, B. S., Jayaraman, K., and Ishak, I. (2013). Factors Influencing Small Medium Enterprises (SMEs) in Obtaining Loan. International Journal of Business and Social Science. Vol. 4, No. 15, [Special Issue], pp. $182-195$

Ibrahim, H. A., and Muhammad M. Y. (2017). Analysis of Constraints to Credit Access for SMEs in Sokoto Metropolis. Asian Journal of Economic Modelling. Vol. 5, No. 2, pp. $187-174$.

IFC (2010). The SME Banking Knowledge Guide. IFC, Washington, DC.

IFC (2011a). Scaling-Up SME Access to Financial Services in the Developing World. IFC, Washington, DC. A report prepared by IFC on behalf of the Global Partnership of Financial Inclusion.

IFC (2011b). Strengthening Access to Finance by Women- Owned Enterprises in Developing Countries. IFC, Washington, DC. A report prepared by IFC on behalf of the Global Partnership of Financial Inclusion.

IFC (2011c). Inclusive Business Models. Guide to the Inclusive Business Models in IFC Portfolio. Client Case Studies. IFC, Washington, DC.

Larry E., (2011). Global Financial Crisis: Five Key Stages 2007 - 2011. Economics editor, The Guardian. Sunday, 7, August, 2011.

Margaret M. (2017). Factors Influencing Small and Medium Size Enterprises Access to Financing: A Case of Kiambu County, Kenya. Unpublished Thesis, United States International University, Africa.

Mina, A., Lahr, H. \& Hughes, A. (2013). The demand and supply of external finance for innovative firms.Industrial and Corporate Change, 22 (4), 869-901.

Muritala A. T. and Yusuf A. B. (2013). Impact of Small and Medium Enterprises on Economic Growth and Develoment. American Journal of Business Management. Vol. 1, No. 1, 2012, 18-22.

Ogujuiba, K. K., Ohuche, F.K. and Adenuga, A.O. (2004).Credit availability to small and medium scale enterprises in Nigeria: Importance of new capital base for banks, background and issues. Working Paper, Available at http://www.valuefronteraonline/publication, july 2016.

Oloye M.I., Obadiaru E. D., Bamigbola A (2015). International Educative Research Foundation 3 (9), 85-87.

Sanusi J.O. (2003) "An over view of Government Effort in the Development of SMEs in Nigeria", Governor Central Bank of Nigeria (CBN) $10^{\text {th }}$ June, 2003.

Stihliz, J and Greenwald B. (2010). Towards A New Global Reserve System. Journal of Globalization and Development. http://www.bepress.com/jgd

Taiwo, J. N., Falohun, T. O., and Agwu, M. E. (2016). SMEs Financing and its Effects on Nigerian Economic Growth. European Journal of Business, Economics and Accountancy, Vol. 4, No. 4, ISSN 2056-6018.

Wan, L., Riding, A. \&Chamberlin,T. (2011). The Global Financial Crisis - Impact on SMEs and public policy responses. Telfor School of Management, University of Ottawa, retrieved from http://www.swinburne.edu.au, july2016.

Weston, J \& Brigham, E. (1981).Management Finance.Hindgale: Dryden Press.

World Bank Group. (2018). Improving Access to Finance for SMEs: Opportunities through Credit Reporting, Secured Lending and Insolvency Practices. May, 2018. 